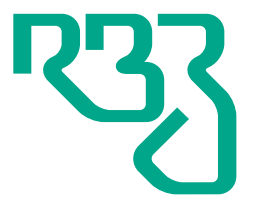

Revista

Brasileira de

Zootecnia

Brazilian Journal of Animal Science

ISSN 1806-9290

www.rbz.org.br

*Corresponding author:

andrezazte@hotmail.com

Received: July 12, 2018

Accepted: February 27, 2019

How to cite: Veras, A. G.; Souza, J. G.; Teixeira,

E. N. M.; Moreira, J. A.; Marinho, A. L.; Diógenes,

G. V.; Ferreira, L. H. G. and Chemane, I. A 2019.

Canola and coconut oils in the feed of European

quails (Coturnix coturnix). Revista Brasileira de

Zootecnia 48:e20180123.

https://doi.org/10.1590/rbz4820180123

Copyright: This is an open access article distributed under the terms of the

Creative Commons Attribution License

(http://creativecommons.org/licenses/by/4.0/),

which permits unrestricted use, distribution,

and reproduction in any medium, provided the

original work is properly cited.

\section{Canola and coconut oils in the feed of European quails (Coturnix coturnix)}

\author{
Aline Guedes Veras ${ }^{1}$ iD, Janete Gouveia de Souza ${ }^{2}$ iD, Elisanie Neiva \\ Magalhães Teixeira $^{2}$ (iD, José Aparecido Moreira ${ }^{2}$ iD, Andreza Lourenço \\ Marinho $^{2 *}$ (iD, Géssica Vitalino Diógenes ${ }^{1}$ (iD, Laíza Hayanne Gomes \\ Ferreira $^{2}$ iD, Isidro Argentina Chemane ${ }^{2}$ iD \\ ${ }^{1}$ Universidade Estadual Paulista, Faculdade de Ciências Agrárias e Veterinárias, Jaboticabal, \\ SP, Brasil. \\ ${ }^{2}$ Universidade Federal do Rio Grande do Norte, Unidade Acadêmica Especializada em \\ Ciências Agrárias, Macaíba, RN, Brasil.
}

\begin{abstract}
The objective of this study was to evaluate the effect of the inclusion of canola and coconut oils to diets of European quail (Coturnix coturnix) over performance and carcass yield. One hundred and ninety-two quail (eight-days old) were randomly allocated to four dietary treatments with six replicates of eight birds each. The treatments were arranged in a factorial $2 \times 2$ scheme with two sources of dietary oil containing two levels of canola and coconut oils ( 1 and $2 \%$ ). For performance variables, the final weight was evaluated, and the carcass variables were feed intake, weight gain, and feed conversion. A significant difference was observed between treatments for feed intake, with the inclusion of $2 \%$ canola oil providing higher intake. There was also significant effect for carcass characteristics on weight at fasting, eviscerated carcass, liver and gizzard weights, as well as liver, heart, and gizzard yields. The inclusion of vegetable oil such as canola and coconut oils in diets for European quail at the levels of 1 and $2 \%$ can be performed with no negative effect on performance from 8 to 42 days of age.
\end{abstract}

Keywords: carcass quality, feed additive, production cost, quail nutrition

\title{
Introduction
}

Brazilian quail breeding is becoming ever more prominent in the aspects of rearing and nutrition, transitioning from a family activity to a commercial-scale production. Advances in production technological innovations, especially in feeding programs, ensure that nutritional requirements are met, leading to good performance (Muniz et al., 2015).

Data from the IBGE (2017) indicated that Brazilian quail production presented an effective 15.5 million quail, an increase of $12.1 \%$. The southeastern region is the most productive $(62.5 \%)$, with the state of São Paulo leading the production with $28.5 \%$ of the national total. According to Silva et al. (2012), Brazil occupies the rank of fifth largest worldwide producer of quail meat and the second in egg production, with constant growth in the many regions of the country, with increasing automated production and new forms of commercializing the product, be it egg or carcass.

Concerning productive efficiency, there are many reasons for the use of lipid sources in animal feeds. Among these are the improvement of palatability, decrease in dustiness and waste of feed, decrease in feed passage rate through the gastrointestinal tract, and low caloric increment of this source of energy, in addition to providing essential fatty acids and liposoluble vitamins (NRC, 1994; Lara et al., 2005). 
Mahgoub et al. (2019) mentioned that medicinal plants and their bioactive elements have been important for the growth of human, poultry, and livestock production related to human health care (Alagawany and Abd El-Hack, 2015; Abdelnour et al., 2018; Dhama et al., 2018). Several studies have reported beneficial antimicrobial effects with utilization of plants with biostimulating properties that act as growth promoters, which could be used as substitutes for antibiotics (Abd El-Hack et al., 2018; Tiwari et al., 2018).

The use of essential oils obtained by cold pressing, such as coconut oil and oils with functional activity such as canola oil, can provide enrichment of quail carcass, as they act as growth promoters (Dabbou et al., 2016).

Dietetic manipulations of bird feed have been used to improve the nutritional quality of the final product (meat and egg), since the availability of fatty acids is related to the reduction of blood pressure and lowdensity lipoprotein (LDL) cholesterol levels, which are related to the predisposition of cardiovascular diseases in humans, thus promoting healthier food, acceptable to the palate and demands of the consumer market (Carvalho et al., 2009).

In this context, the objective was to evaluate the performance and carcass yield of European quail, from 8 to 42 days of age, fed diets enriched with canola and coconut oils.

\section{Material and Methods}

The experiment was conducted in the Municipality of Macaíba, Rio Grande do Norte, Brazil (5 $5^{\circ} 53^{\prime} \mathrm{S}$, $35^{\circ} 23^{\prime} \mathrm{W}$, and average altitude of $40 \mathrm{~m}$ ). All experimental protocols and procedures were approved by the Ethics Committee in Animal Experimentation (CEUA), case no. 018.016/2017.

One hundred and ninety-two quails (eight-days old) were randomly allocated to four dietary treatments with six replicates of eight birds each using a completely randomized design in a $2 \times 2$ factorial arrangement, with two sources of dietary oil containing two levels of canola and coconut oils 11 and $2 \%$ ). The birds were distributed into 24 boxes with dimensions of $1.0 \times 1.5 \mathrm{~m}$, with floor covered with shavings, containing pendular drinker fountains and tubular feeding troughs. A continuous illumination program was adopted (natural + artificial light), and water and feed were provided ad libitum during the entire experimentation period ( 35 days).

The experimental treatments consisted of four different diets, with two levels (1 and 2\%) of vegetable oils (canola and coconut), and formulated rations were isocaloric and isoproteic, according to the nutritional demands advocated by Silva and Costa (2009) for 8 to 21 (Table 1) and 22 to 42 days old (Table 2).

The following parameters were evaluated: final weight $(\mathrm{g})$, weight gain $(\mathrm{g})$, feed intake $(\mathrm{g})$, and feed conversion $\left(\mathrm{g} \mathrm{g}^{-1}\right)$. Feed intake was calculated using the difference between the amount of feed offered and leftovers. Weight gain was determined by the relation of the weights of birds from each plot divided by the number of birds of each experimental unit. With the data of feed intake and weight gain, it was possible to calculate feed conversion using the relation of these values. All weightings were performed weekly using a digital scale.

For carcass evaluation, the absolute (g) and relative (\%) carcass weights, and the weights of the noble cuts (chest and leg quarter) and edible viscera (liver, gizzard, and heart) were evaluated. At the end of the experimental period, two birds per plot were selected according to their average weight (265.6 g), being separately weighted and subjected to feed fasting for $8 \mathrm{~h}$ before slaughter.

Slaughter was conducted by cervical dislocation with subsequent sangria, scalding, defeathering, and evisceration. Posteriorly, the carcasses were weighted to obtain carcass weight and calculate carcass yield. The edible viscera (liver, heart, and gizzard) and cuts (chest and leg quarter) were separated and weighted on a digital scale.

After weighing the carcasses, the relative weight (\%) was calculated in relation to live weight after fasting, using the following formula: Carcass yield $(\%)=$ (eviscerated carcass $\times 100 /$ live weight).

The percentage yield of cuts and edible viscera was performed in function of the weight of the eviscerated carcass, using the formula: cut or viscera yield $(\%)=$ (cut or viscera weight/carcass weight $\times 100$ ) (Carolino et al., 2014).

R. Bras. Zootec., 48:e20180123, 2019 
Table 1 - Feed and nutritional composition of the experimental diets of quail in the phase of 8 to 21 days of age ${ }^{1}$

\begin{tabular}{|c|c|c|c|c|}
\hline \multirow{2}{*}{ Item } & \multicolumn{2}{|c|}{ Canola } & \multicolumn{2}{|c|}{ Coconut } \\
\hline & $1 \%$ & $2 \%$ & $1 \%$ & $2 \%$ \\
\hline \multicolumn{5}{|l|}{ Ingredient ( $\mathrm{g} \mathrm{kg}^{-1}$ dry matter) } \\
\hline Corn grain & 537.20 & 491.31 & 557.62 & 495.10 \\
\hline Soybean bran $45 \%$ & 417.80 & 450.27 & 389.93 & 443.50 \\
\hline Canola oil & 10.00 & 20.00 & - & - \\
\hline Coconut oil & - & - & 10.00 & 20.00 \\
\hline Dicalcium phosphate & 10.70 & 13.79 & 14.12 & 13.80 \\
\hline Limestone & 11.00 & 11.30 & 15.71 & 16.00 \\
\hline Common salt & 3.20 & 3.13 & 3.18 & 3.12 \\
\hline DL-methionine & 2.50 & 2.08 & 2.35 & 2.10 \\
\hline L-lysine HCL & 3.00 & 1.69 & 0.349 & 2.70 \\
\hline Vitamin premix ${ }^{2}$ & 4.00 & 4.00 & 4.00 & 4.00 \\
\hline Mineral premix ${ }^{3}$ & 0.60 & 0.60 & 0.60 & 0.60 \\
\hline Total & 1000 & 1000 & 1000 & 1000 \\
\hline \multicolumn{5}{|l|}{ Nutritional levels ( $\mathrm{g} \mathrm{kg}^{-1}$ dry matter ) } \\
\hline Crude protein & 250.0 & 250.0 & 250.0 & 250.0 \\
\hline Metabolizable energy $\left(\mathrm{Mcal} \mathrm{kg}^{-1}\right)$ & 2.900 & 2.900 & 2.900 & 2.900 \\
\hline Calcium & 8.50 & 10.04 & 10.96 & 8.87 \\
\hline Available phosphorus & 3.20 & 3.80 & 3.80 & 3.80 \\
\hline Potassium & 9.29 & 9.75 & 8.84 & 9.75 \\
\hline Sodium & 1.70 & 1.70 & 1.70 & 1.70 \\
\hline Chloride & 2.18 & 2.15 & 2.21 & 2.15 \\
\hline Digestible lysine & 13.72 & 13.10 & 13.70 & 13.70 \\
\hline Digestible methionine & 5.58 & 5.50 & 5.50 & 5.50 \\
\hline
\end{tabular}

${ }^{1}$ Recommendations of Silva and Costa (2009).

${ }^{2}$ Vitamin A (min), 2,667,000 IU kg-1; vitamin D3 (min), 667,000 IU kg-1; vitamin E (min), 3,334 $\mathrm{IU} \mathrm{kg}^{-1}$; vitamin K3 (min), $667 \mathrm{mg} \mathrm{kg}{ }^{-1}$; vitamin B1 (min), $334 \mathrm{mg} \mathrm{kg}^{-1}$; vitamin B2 (min), 1,334 mg kg-1; vitamin B6 (min), $834 \mathrm{mg} \mathrm{kg}^{-1}$; vitamin B12 (min), 3,667 $\mu \mathrm{g} \mathrm{kg}^{-1}$; niacin (min), 8,334 mg kg-1; calcium pantothenate (min), 3,334 mg kg-1; folic acid (min), $184 \mathrm{mg} \mathrm{kg}^{-1}$; biotin (min), $20 \mathrm{mg} \mathrm{kg}^{-1}$; colin chloride (min), 50 mg kg-1 robenidine, $10.16 \mathrm{~g} \mathrm{~kg}^{-1}$; colistin, $2,154 \mathrm{mg} \mathrm{kg}^{-1}$.

${ }^{3}$ Iron (min), $60 \mathrm{~g} \mathrm{~kg}^{-1}$; copper (min), $13 \mathrm{~g} \mathrm{~kg}^{-1}$; manganese (min), $120 \mathrm{~g} \mathrm{~kg}^{-1}$; zinc (min), $100 \mathrm{~g} \mathrm{~kg}^{-1}$; iodine (min), 2,500 mg kg-1; selenium (min), $500 \mathrm{mg} \mathrm{kg}^{-1}$.

The economic feasibility of using oil in the feed of meat quail was determined according to Bellaver et al. (1985), in which:

$$
\text { Feed cost }(\mathrm{kg})=\frac{(\text { Feed consumption } \times \text { Price per kg of feed })}{\text { Weight gain }}
$$

The calculations of Economic Efficiency Index (EEI) and average cost index (CI) were performed according to Barbosa et al. (1992), using the following equations:

$$
\mathrm{EEI}=\frac{\mathrm{MC} e}{\mathrm{CT} e i} \times 100 \quad \mathrm{CI}=\frac{\mathrm{CT} e i}{\mathrm{MC} e} \times 100
$$

in which $\mathrm{MC} e$ is the lowest average cost of feed per kilogram of gained live weight, observed between treatments; and CTe $i$ is the average cost of treatment $i$.

The prices of ingredients (expressed in $\mathrm{R} \$ /$ kilogram) used to calculate feed costs were collected in the region of Natal, Rio Grande do Norte, Brazil.

The model used for this project was:

$$
Y i j k=\mu+A i+B j+(A B) i j+y k+e i j k,
$$

in which Yijk is the observed value of treatment with canola oil (A), coconut oil treatment (B), within block (k); $\mu$ is the population mean for the variable; $A i$ is the effect of the input level of canola oil; $B j$ is the effect of the input level of coconut oil; $(\mathrm{AB})$ is the effect of the interaction between oil type and inclusion levels; yk is the block effect k; and eijk is the random error associated with ijk treatments. 
Table 2 - Feed and nutritional composition of the experimental diets of quail in the phase of 22 to 42 day of age ${ }^{1}$

\begin{tabular}{|c|c|c|c|c|}
\hline \multirow{2}{*}{ Item } & \multicolumn{2}{|c|}{ Canola } & \multicolumn{2}{|c|}{ Coconut } \\
\hline & $1 \%$ & $2 \%$ & $1 \%$ & $2 \%$ \\
\hline \multicolumn{5}{|l|}{ Ingredient ( $\mathrm{g} \mathrm{kg}^{-1}$ dry matter) } \\
\hline Corn grain & 565.00 & 541.76 & 568.70 & 541.76 \\
\hline Soybean bran $45 \%$ & 390.98 & 396.32 & 389.91 & 396.32 \\
\hline Canola oil & 10.00 & 20.00 & - & - \\
\hline Coconut oil & - & - & 10.00 & 20.00 \\
\hline Dicalcium phosphate & 12.22 & 9.26 & 9.28 & 9.26 \\
\hline Limestone & 9.64 & 21.11 & 9.93 & 21.11 \\
\hline Common salt & 2.88 & 2.93 & 2.95 & 2.93 \\
\hline DL-methionine & 1.90 & 2.00 & 1.90 & 2.00 \\
\hline L-lysine HCL & 2.50 & 2.00 & 2.80 & 2.00 \\
\hline Vitamin premix ${ }^{2}$ & 4.00 & 4.00 & 4.00 & 4.00 \\
\hline Mineral premix ${ }^{3}$ & 0.60 & 0.60 & 0.60 & 0.60 \\
\hline Total & 1000 & 1000 & 1000 & 1000 \\
\hline \multicolumn{5}{|l|}{ Nutritional levels ( $\mathrm{g} \mathrm{kg}^{-1}$ dry matter) } \\
\hline Crude protein & 230.0 & 230.0 & 230.0 & 230.0 \\
\hline Metabolizable energy (Mcal kg-1) & 2.950 & 2.950 & 2.950 & 2.950 \\
\hline Calcium & 8.15 & 11.83 & 7.53 & 9.41 \\
\hline Available phosphorus & 29.0 & 29.0 & 29.0 & 29.0 \\
\hline Potassium & 8.87 & 8.91 & 8.88 & 9.03 \\
\hline Sodium & 1.58 & 1.60 & 1.60 & 1.60 \\
\hline Chloride & 2.04 & 2.06 & 2.08 & 2.05 \\
\hline Digestible lysine & 12.97 & 12.67 & 13.18 & 11.40 \\
\hline Digestible methionine & 5.07 & 5.17 & 5.07 & 5.25 \\
\hline
\end{tabular}

${ }^{1}$ Recommendations of Silva and Costa (2009).

${ }^{2}$ Vitamin A (min), 2,667,000 IU kg-1; vitamin D3 (min), 667,000 IU kg-1; vitamin E (min), 3,334 IU kg-1; vitamin K3 (min), 667 mg kg-1; vitamin B1 (min), $334 \mathrm{mg} \mathrm{kg}^{-1}$; vitamin B2 (min), 1,334 $\mathrm{mg} \mathrm{kg}^{-1}$; vitamin B6 (min), $834 \mathrm{mg} \mathrm{kg}^{-1}$; vitamin B12 (min), 3,667 $\mathrm{ug} \mathrm{kg}^{-1}$; $\mathrm{niacin}_{\text {(min) }}$, 8,334 mg kg-1; calcium pantothenate (min), 3,334 mg kg-1; folic acid (min), $184 \mathrm{mg} \mathrm{kg}^{-1}$; biotin (min), $20 \mathrm{mg} \mathrm{kg}^{-1}$; colin chloride (min), $50 \mathrm{mg} \mathrm{kg}{ }^{-1}$; robenidine $10.16 \mathrm{~g} \mathrm{~kg}^{-1}$; colistin, $2,154 \mathrm{mg} \mathrm{kg}^{-1}$.

${ }^{3}$ Iron (min), $60 \mathrm{~g} \mathrm{~kg}^{-1}$; copper (min), $13 \mathrm{~g} \mathrm{~kg}^{-1}$; manganese (min), $120 \mathrm{~g} \mathrm{~kg}^{-1}$; zinc (min), $100 \mathrm{~g} \mathrm{~kg}^{-1}$; iodine (min), 2,500 mg kg-1; selenium (min), $500 \mathrm{mg} \mathrm{kg}^{-1}$.

The analysis of variance was performed using GLM software of SAS software (Statistical Analysis System, version 9.0$)$, considered significant at $5 \%$ (F test) $(\mathrm{P}<0.05)$, and means were compared by the Tukey test at the $5 \%$ probability level.

\section{Results}

Among the evaluated performance parameters, there were no significant effects for final weight $(P>0.05)$ and weight gain $(P>0.05)$; however, there was interaction $(P<0.05)$ of weight gain with the use of $2 \%$ canola oil in the diet (Table 3 ).

There was no significant difference $(\mathrm{P}>0.05)$ for feed conversion, and there was also no interaction $(P>0.05)$ between treatments. Regarding feed intake, a significant effect $(\mathrm{P}<0.05)$ was observed among the diets, in which the inclusion of $2 \%$ canola oil provided higher feed intake compared with the other treatments, differing from the inclusion of $1 \%$ canola oil and $2 \%$ coconut oil; furthermore, there was interaction $(\mathrm{P}<0.05)$ between the sources of oil within the tested levels, in which birds that received treatment with canola oil consumed more feed than those that received coconut oil.

The evaluations conducted regarding chest, leg quarter, and heart weight presented no significant difference $(\mathrm{P}>0.05)$ among the evaluated treatments, as occurred for carcass, chest, and leg quarter yield (Table 4).

Regarding carcass characteristics, a significant effect $(\mathrm{P}<0.05)$ was observed with the addition of two sources of oil in the diet of quail on weight in fasting and weight of eviscerated carcass. Birds fed diets 
with a higher level of oil inclusion (2\%) presented greater weight in fasting and greater eviscerated carcass weight (Table 4).

Higher weight $(\mathrm{P}<0.05)$ of liver and gizzard were found in birds fed diets with $2 \%$ canola oil. This also occurred for the yield of heart and gizzard, for birds provided with feed containing $1 \%$ coconut oil, and liver, for birds receiving feed with $2 \%$ canola oil, all presenting greater yields. There was no interaction between the sources of oil used within the studied levels $(\mathrm{P}>0.05)$ for any of the analyzed variables.

For gizzard yield, there was difference $(\mathrm{P}<0.05)$ among treatments, with lower values observed for treatments with canola oil, with decrease in gizzard yield insofar as the level of oil inclusion increased.

The analysis of the economic feasibility demonstrated a difference $(\mathrm{P}<0.05)$ among all analyzed variables of the treatments (Table 5).

Table 3 - Performance parameters of European quail fed diets supplemented with canola and coconut oil

\begin{tabular}{|c|c|c|c|c|c|c|c|}
\hline \multirow{2}{*}{ Variable } & \multicolumn{2}{|c|}{ Oil } & \multicolumn{2}{|c|}{ Level } & \multicolumn{3}{|c|}{ Probability } \\
\hline & Canola & Coconut & $1 \%$ & $2 \%$ & Oil & Level & Oil $\times$ level \\
\hline Final weight (g) & 298.41 & 256.45 & 288.11 & 266.75 & 0.144 & 0.448 & 0.7687 \\
\hline Feed intake (g) & $769.85 b$ & $832.90 \mathrm{a}$ & $769.85 b$ & $920.60 a$ & 0.087 & 0.025 & 0.0001 \\
\hline Weight gain (g) & 215.10 & 228.57 & $241.75 a$ & $227.25 b$ & 0.916 & 0.016 & 0.0086 \\
\hline Feed conversion $\left(\mathrm{g} \mathrm{g}^{-1}\right)$ & 3.70 & 3.46 & 3.62 & 3.54 & 0.165 & 0.629 & 0.0703 \\
\hline
\end{tabular}

Means followed by different letters in the same row differ by Tukey's test at $5 \%$ probability.

Table 4 - Means of carcass weight and yield of European quail fed diets supplemented with canola and coconut oil

\begin{tabular}{|c|c|c|c|c|c|c|c|}
\hline \multirow{2}{*}{ Variable } & \multicolumn{2}{|c|}{ Oil } & \multicolumn{2}{|c|}{ Level } & \multicolumn{3}{|c|}{ Probability } \\
\hline & Canola & Coconut & $1 \%$ & $2 \%$ & Oil & Level & Oil $\times$ level \\
\hline \multicolumn{8}{|l|}{ Weight (g) } \\
\hline Fasting & 262.000 & 253.750 & $247.917 b$ & $267.833 a$ & 0.146 & 0.002 & 0.579 \\
\hline Carcass & $180.583 a$ & $171.583 b$ & 173.750 & 178.417 & 0.027 & 0.230 & 0.896 \\
\hline Chest & 72.662 & 68.992 & 70.342 & 71.312 & 0.124 & 0.676 & 0.237 \\
\hline Leg quarter & 42.617 & 40.996 & 41.346 & 42.267 & 0.161 & 0.418 & 0.479 \\
\hline Heart & 2.158 & 1.958 & 2.075 & 2.042 & 0.051 & 0.732 & 0.396 \\
\hline Liver & 4.375 & 4.379 & $3.933 b$ & $4.821 \mathrm{a}$ & 0.992 & 0.033 & 0.431 \\
\hline Gizzard & 3.479 & 3.454 & $3.325 b$ & $3.608 \mathrm{a}$ & 0.842 & 0.033 & 0.108 \\
\hline \multicolumn{8}{|l|}{ Yield (\%) } \\
\hline Carcass & 66.28 & 69.09 & 66.36 & 69.01 & 0.581 & 0.601 & 0.217 \\
\hline Chest & 40.20 & 40.22 & 40.53 & 39.89 & 0.976 & 0.445 & 0.055 \\
\hline Leg quarter & 23.61 & 23.90 & 23.80 & 23.71 & 0.583 & 0.867 & 0.513 \\
\hline Heart & $1.28 \mathrm{~b}$ & $2.22 \mathrm{a}$ & 1.78 & 1.73 & $<0.001$ & 0.614 & 0.190 \\
\hline Liver & 2.42 & 2.55 & 2.27 & 2.70 & 0.553 & 0.055 & 0.388 \\
\hline Gizzard & $1.60 \mathrm{~b}$ & 2.43a & $1.86 \mathrm{~b}$ & $2.17 \mathrm{a}$ & $<0.001$ & 0.027 & 0.360 \\
\hline
\end{tabular}

Means followed by different letters in the same row differ by Tukey's test at $5 \%$ probability.

Table 5 - Economic evaluation of European quail feeds enriched with canola and coconut oils

\begin{tabular}{lccccc}
\hline \multirow{2}{*}{ Variable } & \multicolumn{4}{c}{ Treatment } & \multirow{2}{*}{ CV (\%) } \\
\cline { 2 - 5 } & 1\% Canola & 2\% Canola & $1 \%$ Coconut & 2\% Coconut & \\
\hline Feed cost $(\mathrm{R} \$ / \mathrm{kg})$ & $5.38 \mathrm{ab}$ & $6.17 \mathrm{a}$ & $4.96 \mathrm{~b}$ & $5.23 \mathrm{ab}$ & 10.74 \\
Cost index (\%) & $108.50 \mathrm{ab}$ & $124.43 \mathrm{a}$ & $100.00 \mathrm{~b}$ & $105.36 \mathrm{ab}$ & 10.75 \\
Economic efficiency index $(\%)$ & $91.11 \mathrm{ab}$ & $81.44 \mathrm{~b}$ & $100.58 \mathrm{a}$ & $95.46 \mathrm{ab}$ & 9.23 \\
\hline
\end{tabular}

$\mathrm{CV}$ - coefficient of variation.

Means followed by different letters in the same row statistically differ by Tukey's test at the $5 \%$ significance level. 


\section{Discussion}

The interaction between type and levels of oil on weight gain is related to the significant increase in feed intake due to the increase of oil levels included in the rations. This result is related to the improvement in the quality of rations, since the energy level does not vary between the rations, or to the palatability of the ration that may have interfered in the intake and influenced the weight gain. Corroborating these results, Raber et al. (2008) also observed an increase in the weight gain of broilers fed diets with degummed soybean oil compared with refined soybean oil, which should be an indication that the refined soybean oil has a lower energy value than the degummed soybean oil.

Abd El-Hack et al. (2015) performed an experiment using coconut and rosemary oils and the mixture between them and observed that supplementing meat quail diets with $0.75 \mathrm{~g} \mathrm{~kg}^{-1}$ of the oil mixture slightly decreased daily weight gain and that the $1.5 \mathrm{~g} \mathrm{~kg}^{-1}$ level improved weight gain by 5.27 and $3.85 \%$ in the period from three to six weeks of age and in the total period (one to six weeks of age), respectively, when compared with the control group.

Mahgoub et al. (2019) observed that birds fed diets supplemented with rosemary oil consumed more feed than those fed the control diet and justified that herb and rosemary extracts have an attractive odor that makes the feed tastier, which may have influenced the increase of feed intake. In addition, Abd El-Hack et al. (2015) reported that feed intake was directly correlated with the oil level in the diet and can be attributed to the increased palatability of these medicinal herbs.

The results of feed conversion in the present study corroborate the findings of Pita et al. (2006), who also found nonsignificant difference in feed conversion when layers were fed diets containing two levels (3 and 4\%) of canola oil.

Pinto et al. (2014), evaluating oil sources (soybean, flaxseed, and sardine) and their importance in the performance and immunity of broiler chickens from 1 to 21,1 to 35 , and 1 to 42 days of age, reported that the type of oil added to feed had no influence on performance variables such as weight gain and final weight for any of the tested periods. For feed conversion until 21 and 42 days of age, the authors indicated an increase of this variable when birds were fed diets supplemented with $4 \%$ more of soybean oil. The authors reported that this may have occurred due to the increase in the energy of the feed, influencing a direct response to its conversion for performance.

The increased intake in function of oil levels was possibly related to the increase in palatability of the feed due to the higher oil level, since the amount of energy offered was the same for all treatments. Distinctly from the results of this work, Costa et al. (2008), when evaluating the performance and quality of eggs of semi-heavy hens fed diets containing soybean and canola oils in the levels of $0,1,2$, and $3 \%$, verified no significant effect of the type of oil on feed intake.

Mahgoub et al. (2019), evaluating the use of rosemary oil on intestinal health and performance of Japanese quail, observed improvement in feed conversion of animals fed rosemary oil and reported that extracts derived from medicinal plants tend to increase the secretion of digestive enzymes and, consequently, improve the digestibility of different nutrients, which justifies the improvement observed in feed conversion of growing quail fed diets supplemented with rosemary oil. According to reports in the literature (Jang et al., 2004; Jamroz et al., 2006), essential oils can improve the secretion of amylase and trypsin and can decrease the binding of pathogens such as E. coli to the intestinal wall.

The lack of difference among treatments for carcass, chest, and leg quarter yield may be due to the relation of these variables to genetic factors and, probably, due to the proximity of the oil level used.

The organs evaluated participate, direct or indirectly, in lipid metabolism, and are required in function of the type of oil used and level of inclusion in the feed, presenting increase in weight and yield, which is interesting from the economic perspective, given the possibility for commercialization.

These results related to weight and yield of the liver may be attributed to the size of the lipid chain, since long-chain fatty acids require a longer time for digestion than short-chain fatty acids, which are 
more susceptible to absorption, as unsaturated fatty acids are better absorbed than saturated fatty acids, justifying the increase in liver weight and yield (Gonzáles and Silva, 1999).

For the diets with coconut oil, the animals presented higher gizzard yield, even with the tendency to decreasing the yield with the increase in oil inclusion levels. The reduction in gizzard yield that occurred with the increase in oil inclusion level is probably directly related to the increase in liver yield, since for participating in the metabolic process of lipid digestion, the liver is more required than the gizzard.

Bavaresco et al. (2014) evaluated the effect of the inclusion of canola bran and oil in the diet of double aptitude quail on weight of cuts and edible viscera, observing a significant difference for the variables heart weight and yield for the feed presenting canola and soybean oil. For the remaining variables, such as carcass weight, chest weight, liver weight and yield, and gizzard weight and yield, the use of canola bran (25\%) and canola oil presented no effect.

Mahgoub et al. (2019) observed a significant difference in all carcass characteristics of the animals fed diet with rosemary oil. The authors observed an increase in the percentage of gizzard fat and better carcass and liver weight with the use of 1 and $2 \mathrm{~mL} / \mathrm{kg}$ of rosemary oil treatment compared with the control diet. Abd El-Hack et al. (2015) reported that supplementing quail diet with $1.5 \mathrm{~g}$ oil $/ \mathrm{kg}$ diet mixture, including rosemary oil, represented a $3.72 \%$ increase in carcass yield compared with the control diet.

Regarding the economic viability of the feed used in this experiment, the lowest cost, the best cost index, and the highest economic efficiency were obtained using the treatment with $1 \%$ coconut oil, which, despite having a relatively high price and being superior to the canola oil, provided better performance to the animals, thus presenting better efficiency in feed usage.

The average cost of feed with the other treatments ( 1 and $2 \%$ canola and $2 \%$ coconut oils) had a negative impact on the economic efficiency index, both due to the percentage of ingredients included in the feed (mainly corn and soybean) and the animal performance parameters, mainly weight gain, which were lower than those of animals fed feed containing $1 \%$ coconut oil.

When evaluating the use of organic acid, essential oils, and symbiotic in the feeding of semidried hens, Vasconcelos et al. (2016) also reported differences in the cost of the rations used, in which the lowest cost was obtained with the control treatment and the highest with the treatment that used organic acids (sorbic, fumaric, malic, citric acid) associated with the essential oils (eugenol, thyme, and vanillin). The authors justified the differences found as a result of the variation in feed intake of the animals.

In a study using crude glycerin for meat quails of 1 to 14 and 15 to 35 days of age, Pasquetti et al. (2014) observed that the feed without crude glycerin had the worst cost indices and economic efficiency indices in both periods. The authors reported that these data are important, since by also considering the animal growth, the use of crude glycerin proved to be a good source of energy, besides being economically viable.

\section{Conclusions}

The addition of canola and coconut oils at $1 \%$ to diets of European quail can be used without negative effects on performance or carcass parameters to promote improvements in weight gain of 8 to 42-day-old quail and present better economic indexes in production.

\section{Acknowledgments}

The authors acknowledge the Brazilian governmental research support institution Conselho Nacional de Desenvolvimento Científico e Tecnológico (CNPq) for the master's degree scholarship granted to the first author. 


\section{References}

Abd El-Hack, M. E.; Mahgoub, S. A.; Alagawany, M. and Dhama, K. 2015. Influences of dietary supplementation of antimicrobial cold pressed oils mixture on growth performance and intestinal microflora of growing Japanese quails. International Journal of Pharmacology 11:689-696. https://doi.org/10.3923/ijp.2015.689.696

Abd El-Hack, M. E.; Mahgoub, S. A.; Hussein, M. M. A. and Saadeldin, I. M. 2018. Improving growth performance and health status of meat-type quail by supplementing the diet with black cumin cold-pressed oil as a natural alternative for antibiotics. Environmental Science and Pollution Research 25:1157-1167. https://doi.org/10.1007/s11356-017-0514-0

Abdelnour, S.; Alagawany, M.; Abd El-Hack, M. E.; Sheiha, A. M.; Saadeldin, I. M. and Swelum, A. A. 2018. Growth, carcass traits, blood hematology, serum metabolites, immunity, and oxidative indices of growing rabbits fed diets supplemented with red or black pepper oils. Animals 8:168. https://doi.org/10.3390/ani8100168

Alagawany, M. and Abd El-Hack, M. E. 2015. The effect of rosemary herb as a dietary supplement on performance, egg quality, serum biochemical parameters, and oxidative status in laying hens. Journal of Animal and Feed Sciences 24:341-347. https://doi.org/10.22358/jafs/65617/2015

Barbosa, H. P.; Fialho, E. T.; Ferreira, A. S.; Lima, G. J. M. M. and Gomes, M. F. M. 1992. Triguilho para suínos nas fases inicial de crescimento, crescimento e terminação. Revista da Sociedade Brasileira de Zootecnia 21:827-837.

Bavaresco, C.; Moraes, P. O.; Gopinger, E.; Dias, R. C.; Xavier, E. G. and Roll, V. F. B. 2014. Qualidade interna e externa de ovos de codornas alimentadas com farelo e óleo de canola. In: Anais do 6o Congresso Latino-Americano de Nutrição Animal Trabalhos Científicos AVES, Estância de São Paulo.

Bellaver, C.; Fialho, E. T.; Protas, J. F. S. and Gomes, P. C. 1985. Radícula de malte na alimentação de suínos em crescimento e terminação. Pesquisa Agropecuária Brasileira 20:969-974.

Carolino, A. C. X. G.; Silva, M. C. A.; Litz, F. H.; Fagundes, N. S. and De Abreu Fernandes, E. A. 2014. Rendimento e composição de carcaça de frangos de corte alimentados com dietas contendo sorgo grão inteiro. Bioscience Journal 30:1139-1148.

Carvalho, P. R.; Pita, M. C. G.; Piber Neto, E. and Mendonça Junior, C. X. 2009. Influência da adição de fontes marinhas ricas em PUFAs na dieta sobre a composição lipídica e percentuais de incorporação de PUFAs N-3 na gema de ovo. Arquivos do Instituto Biológico 76:27-39.

Costa, F. G. P.; Souza, C. J.; Goulart, C. C.; Lima Neto, R. C.; Costa, J. S. and Pereira, W. E. 2008. Desempenho e qualidade dos ovos de poedeiras semipesadas alimentadas com dietas contendo óleos de soja e canola. Revista Brasileira de Zootecnia 37:1412-1418. https://doi.org/10.1590/S1516-35982008000800011

Dabbou, S.; Rotolo, L.; Kovitvadhi, A.; Bergagna, S.; Dezzutto, D.; Barbero, R.; Rubiolo, P.; Schiavone, A.; De Marco, M.; Helal, A. N.; Zoccarato, I. and Gasco, L. 2016. Rabbit dietary supplementation with pale purple coneflower. 1. Effects on the reproductive performance and immune parameters of does. Animal 10:1101-1109. https://doi.org/10.1017/ S1751731115002979

Dhama, K.; Karthik, K.; Khandia, R.; Munjal, A.; Tiwari, R.; Rana, R.; Khurana, S. K.; Ullah, S.; Khan, R. U.; Alagawany, M.; Farag, M. R.; Dadar, M. and Joshi, S. K. 2018. Medicinal and therapeutic potential of herbs and plant metabolites/extracts countering viral pathogens - current knowledge and future prospects. Current Drug Metabolism 19:236-263.

Gonzáles, F. H. D. and Silva, S. C. 1999. Introdução à bioquímica clínica veterinária. UFRGS, Porto Alegre.

IBGE - Instituto Brasileiro de Geografia e Estatística. 2017. Produção da Pecuária Municipal 45:1-9. Available at: <https://biblioteca.ibge.gov.br/visualizacao/periodicos/84/ppm_2017_v45_br_informativo.pdf>.

Jamroz, D.; Wertelecki, T.; Houszka, M. and Kamel, C. 2006. Influence of diet type on the inclusion of plant origin active substances on morphological and histochemical characteristics of the stomach and jejunum walls in chicken. Journal of Animal Physiology and Animal Nutrition 90:255-268. https://doi.org/10.1111/j.1439-0396.2005.00603.x

Jang, I. S.; Ko, Y. H.; Yang, H. Y.; Ha, J. S.; Kim, J. Y.; Kim, J. Y.; Kang, S. Y.; Yoo, D. H.; Nam, D. S.; Kim, D. H. and Lee, C. Y. 2004. Influence of essential oil components on growth performance and the functional activity of the pancreas and small intestine in broiler chickens. Asian-Australasian Journal of Animal Sciences 17:394-400. https://doi.org/10.5713/ ajas.2004.394

Lara, L. J. C.; Baião, N. C.; Aguilar, C. A. L.; Cançado, S. V.; Fiuza, M. A. and Ribeiro, B. R. C. 2005. Efeito de fontes lipídicas sobre o desempenho de frangos de corte. Arquivo Brasileiro de Medicina Veterinária e Zootecnia 57:792-798. https://doi.org/10.1590/S0102-09352005000600014

Mahgoub, S. A. M.; El-Hack, M. E. A.; Saadeldin, I. M.; Hussein, M. A.; Swelum, A. A. and Alagawany, M. 2019. Impact of Rosmarinus officinalis cold-pressed oil on health, growth performance, intestinal bacterial populations, and immunocompetence of Japanese quail. Poultry Science 98:2139-2149. https://doi.org/10.3382/ps/pey568

Muniz, J. C. L.; Barreto, S. L. T.; Viana, G. S.; Reis, R. S.; Mencalha, R.; Barbosa, L. M. R. and Ferreira, R. C. 2015. Desempenho e qualidade de ovos de codornas japonesas alimentadas com diferentes rações comerciais. Revista Brasileira de Agropecuária Sustentável 5:95-100. 
NRC - National Research Council. 1994. Nutrient requeriments of poultry. 9th ed. National Academy of Sciences, Washington, DC

Pasquetti, T. J.; Furlan, A. C.; Martins, E. N.; Ton, A. P. S.; Batista, E.; Pozza, P. C.; Grieser, D. O. and Zancanela, V. 2014. Glicerina bruta para codornas de corte, de um a 14 e de 15 a 35 dias de idade. Arquivo Brasileiro de Medicina Veterinária e Zootecnia 66:1547-1556. https://doi.org/10.1590/1678-7225

Pinto, M. F.; Lima, V. M. F.; Ribeiro, S. C.; Bossolani, I. L. C.; Ponsano, E. H. G. and Garcia-Neto, M. 2014. Fontes de óleo na dieta e sua influência no desempenho e na imunidade de frangos de corte. Pesquisa Veterinária Brasileira 34:409-414. https://doi.org/10.1590/S0100-736X2014000500004

Pita, M. C. G.; Piber Neto, E.; Carvalho, P. R. and Mendonca Junior, C. X. 2006. Efeito da suplementação de linhaça, óleo de canola e vitamina E na dieta sobre as concentrações de ácidos graxos poliinsaturados em ovos de galinha. Arquivo Brasileiro de Medicina Veterinária e Zootecnia 58:925-931. https://doi.org/10.1590/S0102-09352006000500031

Raber, M. R.; Ribeiro, A. M. L.; Kessler, A. M.; Arnaiz, V. and Labres, R. V. 2008. Desempenho, metabolismo e níveis plasmáticos de colesterol e triglicerídeos em frangos de corte alimentados com óleo ácido e óleo de soja. Ciência Rural 38:1730-1736. https://doi.org/10.1590/S0103-84782008000600037

Silva, J. H. V. and Costa, F. G. P. 2009. Tabela para codornas japonesas e europeias. 2.ed. FUNEP, Jaboticabal.

Silva, J. H. V.; Jordão Filho, J.; Costa, F. G. P.; Lacerda, P. B.; Vargas, D. G. V. and Lima, M. R. 2012. Exigências nutricionais de codornas. Revista Brasileira de Saúde e Produção Animal 13:775-790. https://doi.org/10.1590/S151999402012000300016

Tiwari, R.; Latheef, S. K.; Ahmed, I.; Iqbal, H. M. N.; Bule, M. H.; Dhama, K.; Samad, H. A.; Karthik, K.; Alagawany, M.; Abd El-Hack, M. E.; Yatoo, M. I. and Farag, M. R. 2018. Herbal immunomodulators - A remedial panacea for designing and developing effective drugs and medicines: current scenario and future prospects. Current Drug Metabolism 19:264-301.

Vasconcelos, F. C.; Bastos-Leite, S. C.; Gomes, T. C. L.; Goulart, C. C.; Sousa, A. M. and Fontenele, G. S. P. 2016. Ácidos orgânicos, óleos essenciais e simbiótico na dieta de poedeiras semipesadas: desempenho produtivo e análise econômica. Acta Veterinaria Brasilica 10:194-200. 